\title{
A Concentric Analysis of the Impact of Urbanization on the Threatened European Tree Frog in an Agricultural Landscape
}

\author{
JÉRÔME PELLET, ${ }^{*}$ ANTOINE GUISAN, AND NICOLAS PERRIN \\ Laboratory for Conservation Biology, Department of Ecology and Evolution, University of Lausanne, \\ CH-1015 Dorigny, Switzerland
}

\begin{abstract}
Pond-breeding amphibians are affected by site-specific factors and regional and landscape-scale patterns of land use. Recent anthropogenic landscape modifications (drainage, agriculture intensification, larger road networks, and increased traffic) affect species by reducing the suitable habitat area and fragmenting remaining populations. Using a robust concentric approach based on permutation tests, we evaluated the impact of recent landscape changes on the presence of the endangered European tree frog (Hyla arborea) in wetlands. We analyzed the frequency of 1 traffic and 14 land-use indices at 20 circular ranges (from 100-m up to 2-km radii) around 76 ponds identified in western Switzerland. Urban areas and road surfaces bad a strong adverse effect on tree frog presence even at relatively great distances (from $100 \mathrm{~m}$ up to $1 \mathrm{~km}$ ). When traffic measurements were considered instead of road surfaces, the effect increased, suggesting a negative impact due to a vehicle-induced effect. Altogether, our results indicate that urbanization and traffic must be taken into account when pond creation is an option in conservation management plans, as is the case for the European tree frog in western Switzerland. We conclude that our easy-to-use and robust concentric method of analysis can successfully assist managers in identifying potential sites for pond creation, where probability of the presence of tree frogs is maximized.
\end{abstract}

Key Words: amphibian conservation, calling males, circular buffers, Hyla arborea, traffic density, urban areas Un Análisis Concéntrico del Impacto de la Urbanización sobre la Rana Arborícola Europea Amenazada en un Paisaje Agrícola

Resumen: Los anfibios que se reproducen en charcas son afectados por factores específicos del sitio y por patrones a nivel región y paisaje. Modificaciones antropogénicas recientes del paisaje (drenaje, intensificación agrícola, redes carreteras más extensas e incremento de tráfico) afectan a las especies al reducir el área de hábitat adecuado y fragmentar a las poblaciones. Evaluamos el impacto de cambios recientes en el paisaje sobre la presencia de la rana arborícola Europea (Hyla arborea) en bumedales mediante un método concéntrico robusto basado en pruebas de permutación. Analizamos la frecuencia de 1 índice de tráfico y 14 índices de uso de suelo en 20 parcelas circulares (de $100 \mathrm{~m}$ basta $2 \mathrm{~km}$ de radio) alrededor de 76 charcas identificadas en el oeste de Suiza. Las áreas urbanas y las superficies de carreteras tuvieron fuertes efectos adversos sobre la presencia de ranas aún a distancias relativamente grandes (de $100 \mathrm{~m}$ basta $1 \mathrm{~km}$ ). Cuando consideramos las medidas de tráfico en lugar de las superficies de carreteras, el efecto aumentó, sugiriendo un impacto negativo debido a un efecto inducido por vebículos. En general, nuestros resultados indican que la urbanización y el tráfico deben ser considerados cuando la creación de charcas es una opción en los planes de gestión de conservación, como es el caso para la rana arborícola Europea en el oeste de Suiza. Concluimos que nuestro

*email jerome.pellet@ie-zea.unil.ch

Paper submitted September 16, 2003; revised manuscript accepted March 25, 2004. 
método concéntrico de análisis, fácil de usar y robusto, puede ayudar a que gestores identifiquen exitosamente sitios potenciales para la creación de charcas, donde se maximice la probabilidad de presencia de ranas arborícolas.

Palabras Clave: amortiguamientos circulares, áreas urbanas, conservación de anfibios, densidad de tráfico, Hyla arborea, machos llamadores

\section{Introduction}

Decline in local and regional amphibian fauna has been documented by herpetologists and conservation biologists worldwide (Blaustein et al. 1994; Alford \& Richards 1999; Houlahan et al. 2000; Blaustein et al. 2002; Green 2003). In densely populated landscapes, such as the Swiss agricultural plateau, most amphibian species show a clear geographical range contraction (Grossenbacher 1988). Uniformly distributed throughout Switzerland at the beginning of the twentieth century, the European tree frog (Hyla arborea) is now restricted to a few metapopulations completely isolated from one another (Pellet \& Neet 2001), with local populations undergoing regular extinctions and recolonization events (J.P. \& N.P., unpublished data). The tree frog is therefore considered a highly endangered species in Switzerland (Duelli 1994) and has been protected since 1968 .

Habitat loss or deterioration and landscape fragmentation are the leading factors in local population extinction (Dellis et al. 1996; Alford \& Richards 1999; Semlitsch 1998; Semlitsch \& Bodie 1998). As for the tree frog, many causes of decline have been identified at the pond scale, such as fish introduction (Brönmark \& Edenhamn 1994), competition (Fog 1988; Pavignano et al. 1990; Tester 1990), water pollution (Stumpel \& Hanekamp 1986; Tester 1990), eutrophication (Fog 1988), and natural succession (Tester 1990; Grosse 1994; Geiger 1995). At larger scales, factors such as the reduction of terrestrial habitat (Tester 1990; Borgula 1993; Stumpel 1993) and pond isolation (Edenhamn 1996; Vos 1999) are influencing tree frog distribution. It is also clear that landscapelevel changes in land use have direct and indirect effects on amphibian populations (Findlay \& Houlahan 1997; Green 1997; Lehtinen et al. 1999; Pope et al. 2000; Johnson et al. 2002; Welsh et al. 2002; Pellet et al. 2004).

Recent anthropogenic modifications of the agricultural landscape in western Switzerland include transitions from grazed pastures and natural meadows to peri-urban developments or intensive crop plantations, drainage of marshes and wetlands, and road construction. Distribution of European tree frogs should reflect anthropogenic changes such as reduced terrestrial habitat (Vos 1999), impeded migration between ponds (Sjögren-Gulve \& Ray 1996; Vos 1999), modified pond hydrology, and increased human disturbance.

We developed a concentric approach to evaluate the impact of land use on the presence or absence of tree frogs in ponds. This method allows one to identify critical elements in the landscape to estimate the range at which they influence species distribution. Our goal was to evaluate to what extent these landscape modifications affect the European tree frog. Evaluating the effects of land uses on the presence of focal species should then allow us to determine how landscape management and amphibian conservation in a densely populated agricultural landscape could be improved.

\section{Methods}

\section{Species}

The European tree frog is one of the smallest terrestrial anurans (4-6 cm snout-to-vent length) of Western Europe. Breeding, oviposition, and tadpole development take place in a wide range of wetlands, from gravel pits to lake shores (Grosse \& Nöllert 1993). During the breeding period, males call conspicuously to attract gravid females (Schneider 1993). Counts of calling males are used to evaluate the size of breeding populations (Edenhamn 1996; Carlson \& Edenhamn 2000). The terrestrial habitat consists of perennial herbs, shrubs, and hedgerows, almost always characterized by a high sun exposure, allowing individuals to bask during daytime (Stumpel 1993). Migrations to ponds occur during early April in Switzerland, and dispersal of breeders from the site usually happens 2 months later (Fog 1993). Metamorphs leave the water between July and August and can be found in the shore vegetation until the end of September. Dispersal of froglets to terrestrial hibernation sites usually occurs before the first night frosts.

\section{Study Area and Census}

Our study area was located in western Switzerland between the villages of Allaman and Bière $\left(46^{\circ} 30^{\prime} \mathrm{N}, 6^{\circ} 25^{\prime} \mathrm{E}\right)$ and covered $396 \mathrm{~km}^{2}$, of which only $0.5 \%$ constituted amphibian breeding ponds. We identified ponds based on various national databases and field knowledge (Pellet et al. 2002).

The landscape is typical of the Swiss Plateau and is mainly agricultural, with medium-sized villages (2002500 inhabitants) connected by a relatively dense communication network, including highways, primary roads, secondary roads, and railroads. 
Tree frog censuses took place during the spring of 2001 and 2002. Each potential calling pond in the area was surveyed for tree frogs at least three times during the breeding season (mid-April to late June). Because a previous study estimated the detection probability to be as high as 0.94 for each visit (J. P. \& B. Schmidt, unpublished data), this method ensured that tree frog presence was unlikely to go undetected (Edenhamn 1996). Ponds were defined as occupied (1) when at least one calling male was heard during one of the two field seasons. All other ponds were defined as empty (0). The presence of calling males is an indicator of reproductive activity that can be easily compared between ponds with variable shore accessibility. The presence or absence of calling male tree frogs was thus used as the binary response variable in further analyses.

\section{Landscape and Traffic Data}

Landscape data originated from the Vector25 database, which is the vector format of the 1:25,000 topographical maps of Switzerland. The database is provided by the Office Fédéral de la Topographie, and the precision of the data can be estimated at approximately 3-8 $\mathrm{m}$ in flat areas (SWISSTOPO 2003). We used a subset of the complete coverage containing only "primary surfaces," which includes basic land uses such as urban areas, forests, marshes, and arable lands. We aggregated these geographical data into 14 categories to reflect major changes in substratum (e.g., urban vs. agriculture) and potential human disturbance sources (e.g., road1class and railroads) (Table 1).

Traffic data were provided by the Service des Routes du canton de Vaud for all primary roads in the study area. For each first-class road segment in the geographic information system (GIS), the traffic load was expressed as a mean number of vehicles per hour (mvh).

\section{Concentric Analyses}

For our concentric method we created 20 circular buffers (from a $100-\mathrm{m}$ radius up to a $2000-\mathrm{m}$ radius, in $100-\mathrm{m}$ increments) around each of our 76 study ponds. Radii up to $2 \mathrm{~km}$ are justified because this tree frog travels great distances (Fog 1993; Vos 1999). In each buffer, we calculated the frequency of all 14 land-use categories as the sum of the surface for a given land use divided by the surface of the buffer, and we repeated this operation for each of the $20 \times 76$ buffers. We also calculated a traffic impact index (traffic) inside each buffer as the sum of all road segments (in meters) multiplied by the mvh of each segment, the total being divided by the buffer area and by $10^{6}$ for clarity (Table 1 ). Fourteen land-use frequencies and one traffic index calculated in 20 nested concentric buffers yielded a total of 300 predictors tested against tree frog presence or absence. We named predictors after the land use they described and the radius at which they were
Table 1. The 15 landscape and land-use predictors of tree frog presence or absence. ${ }^{*}$

\begin{tabular}{|c|c|}
\hline $\begin{array}{l}\text { Predictor } \\
\text { abbreviation }\end{array}$ & Description \\
\hline Ponds & number of ponds included in the buffer \\
\hline Occupied ponds & $\begin{array}{l}\text { number of ponds included in the buffer } \\
\text { where tree frogs were detected at } \\
\text { least once during the survey }\end{array}$ \\
\hline Lake & frequency of lakes \\
\hline Urban & $\begin{array}{l}\text { frequency of urban areas (isolated } \\
\text { houses or farms not included) }\end{array}$ \\
\hline Vine & frequency of vineyards \\
\hline Orchard & frequency of orchards \\
\hline Road1class & $\begin{array}{l}\text { total length of first-class roads divided by } \\
\text { buffer area }\end{array}$ \\
\hline Road2class & $\begin{array}{l}\text { total length of second-class roads } \\
\text { divided by buffer area }\end{array}$ \\
\hline Marsh & frequency of marshes \\
\hline Bush & frequency of bushes and hedgerows \\
\hline River & $\begin{array}{l}\text { total length of rivers divided by buffer } \\
\text { area }\end{array}$ \\
\hline Mineral & $\begin{array}{l}\text { frequency of bare soil (gravel pits or } \\
\text { military training grounds) }\end{array}$ \\
\hline Highway & $\begin{array}{l}\text { total length of highways divided by } \\
\text { buffer area }\end{array}$ \\
\hline Railroad & $\begin{array}{l}\text { total length of railroads divided by buffer } \\
\text { area }\end{array}$ \\
\hline Traffic & $\begin{array}{l}\text { sum of each first-class road segment } \\
\text { multiplied by its traffic load, measured } \\
\text { as mean number of vehicles per hour } \\
\text { (mvh), the total being divided by } \\
\text { buffer area }\end{array}$ \\
\hline
\end{tabular}

*Predictors are composed of the name of the land use they describe and the radius of the buffer at which they have been computed. Frequencies are calculated as the sum of the land use contained in the buffer, divided by the total buffer area.

calculated (e.g., forest 1700 represents the frequency of forests closer than $1700 \mathrm{~m}$ from a given pond).

To ensure that ponds were independently distributed over our landscape and not located in clusters of occupied and empty ponds (i.e., no spatial autocorrelation), we analyzed our data set to check whether the response variable could be predicted with pond-based variables. If this was not the case, the ponds could appropriately be considered independent of one another and the speciesenvironment statistical tests considered valid. To test that, we created two sets of predictors reflecting the density of both ponds and tree frogs (Table 1). The density of ponds was simply expressed by the number of ponds (empty and occupied) in each buffer (ponds), whereas tree frog density was expressed as the number of occupied ponds in each buffer (occupied ponds). We computed these predictors at each radius in the same fashion as the landscape predictors and analyzed them statistically in the same way. Ponds can be considered independent units (which validates our statistical inferences) if none of these two sets of predictors affect tree frog presence. 


\section{Statistical Methods}

To determine the influence of land use on tree frog presence or absence, we used binary logistic regressions (Sokal \& Rohlf 1995). All predictors whose univariateexplained deviance $\left(D^{2}\right)$ and regression coefficient were both significant at the $5 \%$ level were kept as relevant models (Hosmer \& Lemeshow 1989). Because the number of predictors used was relatively high in relation to our sample size, we then validated the remaining significant models with the permutation methods described by Jaberg and Guisan (2001). The permutation method recalculates the explained deviance of each fitted model with 1000 random permutations of the response variable (in our case, the presence or absence of callers). When explained deviances higher than the one measured occur in more than $5 \%$ of the permutations, the model cannot be considered robust because the observed deviance can be statistically observed by chance alone. Such an empirical randomization test allows the selection of only the most robust models because it is more restrictive than traditional statistical inferences.

\section{Results}

Tree frog choruses were heard in 27 of the 76 study ponds (prevalence of 36\%). None of the first set of predictors (ponds and occupied ponds) were significantly correlated with presence or absence of tree frogs at any radius when the spatial distribution of ponds was analyzed. Of the 15 land uses and traffic indices we chose (Table 1), 4 (marsh, urban, road1class, and traffic) were significantly correlated with tree frog presence, at radii varying from $100 \mathrm{~m}$ to $1000 \mathrm{~m}$ (Table 2).

The frequency of marshes (marsh) had a significant positive effect on the presence of tree frogs when situated close to ponds. The amplitude of the effect was relatively low $\left(D^{2}=5 \%\right)$, and the two models based on marshes (marshes200 and marshes300) did not withstand the validation step, with probabilities of obtaining a higher explained deviance by chance alone being $6 \%$ and $10 \%$, respectively.

The frequency of urban areas (urban) had a strong negative effect on the occurrence of tree frog presence. This effect was measured from a close range $(100 \mathrm{~m})$ up to $1000 \mathrm{~m}$. The explained deviance of models based on urban areas was as high as $14 \%$ at $400 \mathrm{~m}$. All models based on urban areas resisted the permutation step, emphasizing the amplitude of the observed effect, even at extreme radii $(100 \mathrm{~m}$ and $1 \mathrm{~km})$. The explained deviance of urban models increased up to $300 \mathrm{~m}$ and then decreased until becoming nonsignificant at the 1000-m threshold (Fig. 2). Models based on urban areas were not significant over the 1000-m threshold.

The density of first-class roads also showed a negative effect on chorus presence, but only at a range of $200 \mathrm{~m}$.
Table 2. Land use and traffic indices (concentric variable and radius) significantly correlated with presence of tree frogs.

\begin{tabular}{lccc}
$\begin{array}{l}\text { Concentric } \\
\text { variable and } \\
\text { radius }(m)\end{array}$ & $\begin{array}{c}\text { Sign of the } \\
\text { coefficient }\end{array}$ & $\begin{array}{c}\text { Explained } \\
\text { deviance } \\
(\%)\end{array}$ & $\begin{array}{c}\text { Permutation } \\
\text { resistance } \\
(\mathrm{p})^{*}\end{array}$ \\
\hline Marsh200 & + & 5 & $\mathrm{~ns}$ \\
Marsh300 & + & 5 & $\mathrm{~ns}$ \\
Urban100 & - & 7 & $<0.05$ \\
Urban200 & - & 9 & $<0.05$ \\
Urban300 & - & 14 & $<0.001$ \\
Urban400 & - & 14 & $<0.001$ \\
Urban500 & - & 11 & $<0.001$ \\
Urban600 & - & 9 & $<0.001$ \\
Urban700 & - & 8 & $<0.001$ \\
Urban800 & - & 8 & $<0.01$ \\
Urban900 & - & 7 & $<0.01$ \\
Urban1000 & - & 5 & $<0.01$ \\
Road1class200 & - & 6 & $<0.01$ \\
Traffic100 & - & 5 & $<0.05$ \\
Traffic200 & - & 8 & $<0.05$ \\
Traffic300 & - & 6 & $<0.01$ \\
Traffic400 & - & 8 & $<0.01$ \\
\hline
\end{tabular}

*Abbreviation: ns, not significant.

The effect was low (only 6\%) but resistant to permutation. When traffic data were used instead of surface density on first-class roads, the effect, still negative, rose up to $8 \%$, and its range of influence widened from $100 \mathrm{~m}$ up to $400 \mathrm{~m}$ (Fig. 1). The geographical data used for both figures (road1class and traffic) were the same but were balanced by traffic indices in the traffic predictor. There were increasing differences of traffic load around empty and occupied ponds at the four significant radii (100$400 \mathrm{~m}$ ) (Fig. 2).

By removing from the landscape all surfaces less suitable for tree frogs, we were able to geographically visualize the area with the maximum probability of tree frog presence. We adopted a conservative approach when drawing such maps by using buffer distances $100 \mathrm{~m}$ larger than the largest significant one (e.g., using $500 \mathrm{~m}$ when the largest significant traffic buffer was $400 \mathrm{~m}$ ). Based on our models, we mapped all surfaces that were farther than $1100 \mathrm{~m}$ from urban areas and $500 \mathrm{~m}$ from first-class roads. Forests were also excluded from these surfaces because the European tree frog never reproduces in forest ponds (Grosse 1994). With this map we located potential sites for pond creation, where landscape-scale factors would not adversely affect tree frog populations (Fig. 3).

The lake shores, being densely populated, present too dense a network of roads and urban areas to optimally suit tree frogs. Only the northwestern part, less developed, contains suitable surfaces. The remaining suitable portions of the landscape are relatively small and usually located near forest borders. These surfaces are mostly arable lands and pastures. Only a few occupied ponds are located in the potentially suitable surfaces, so pond localization in our study area was not optimal. 

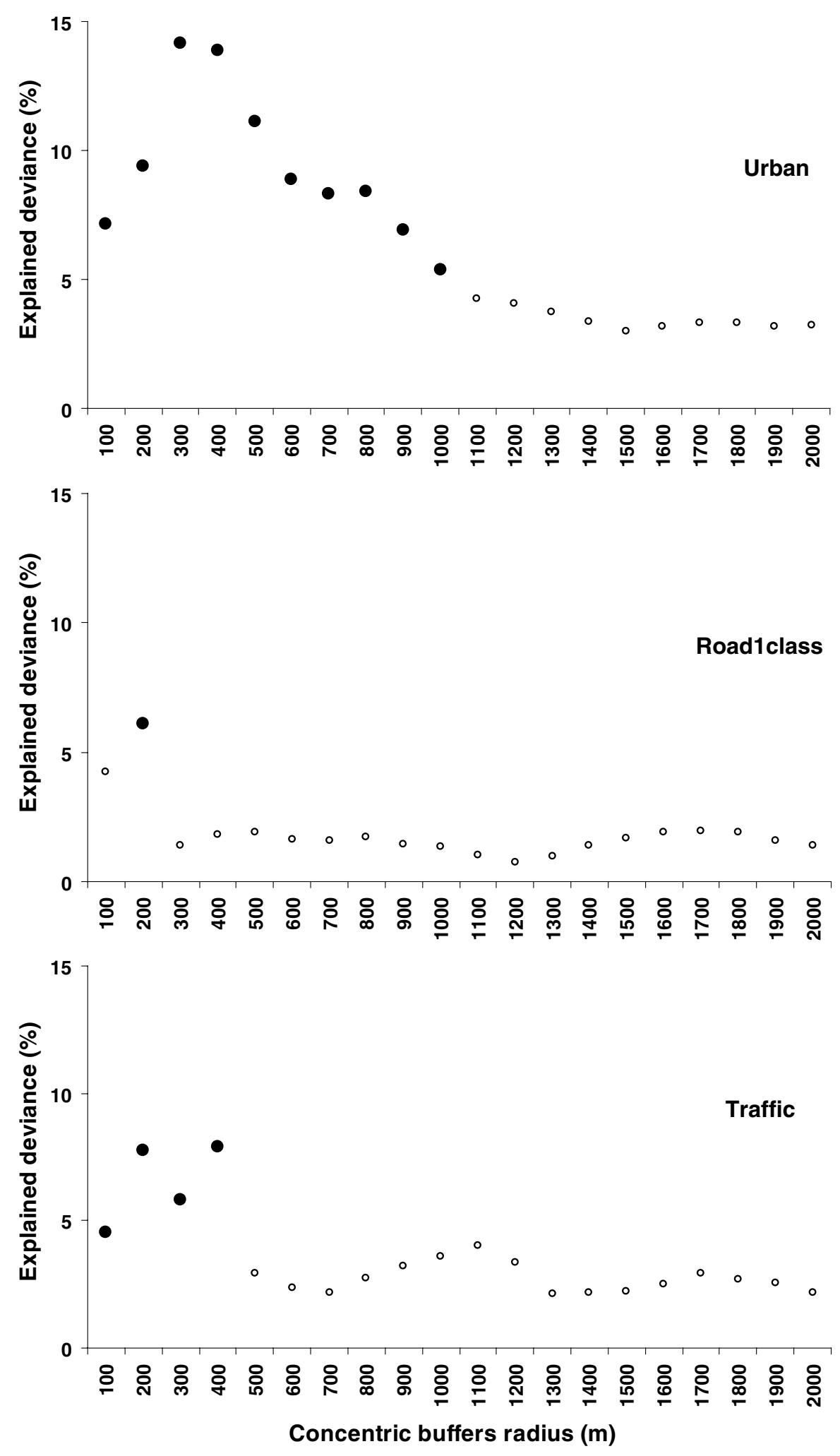

Figure 1. Explained deviance of models based on urban areas, first-class roads, and traffic at 20 radii. Filled circles indicate significant models at $5 \%$ threshold; open circles indicate nonsignificant models.

\section{Discussion}

Our results obtained from the first set of predictors, which reflect pond and tree frog densities, emphasize that in our study area tree frogs are distributed regardless of pond density and conspecific individual local abundance. Hence, ponds can be regarded as independent of one another. 


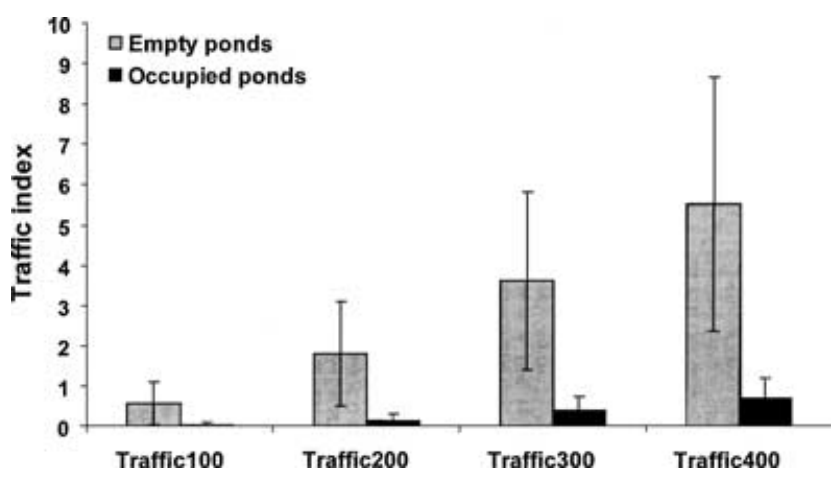

Figure 2. Traffic indices measured at four significant radii $(100-400 \mathrm{~m}$ ) around empty and occupied ponds ( $\pm 95 \%$ confidence interval). Traffic indices are calculated as the sum of all lengths of first-class road segment multiplied by their traffic load (mean vebicles per bour), the total being divided by the buffer area and $10^{6}$ for clarity.

By using one traffic and 14 land-use predictors readily available in most GIS, we were able to highlight the strong negative effect of anthropogenic land uses on tree frog presence in ponds. We also evaluated the range of influence of each land use with statistical models based on systematic concentric buffers.

Models based on the frequency of marshes explained only a relatively small part of the deviance and did not withstand the validation procedure with permutations. Edenhamn (1996) found a positive effect of marsh frequency on the regularity of reproduction of the European tree frog in southern Sweden. In our landscape, marshes are more scattered than in Sweden, usually located in less densely populated areas and in extensively exploited agricultural surfaces. It is probable that the low occurrence of marshes (zero values in the marshes predictors) in western Switzerland explains the fact that models based on this land use were not resistant to the permutation step.

The influence of urban areas had by far the strongest effect on tree frog presence. Our landscape is more densely populated than the landscapes in previous studies of tree frogs (Zealand Flanders, Netherlands: Vos 1999; southern Sweden: Edenhamn 1996), which thus increases the probability of finding a human-induced effect. The impact was significant up to $1 \mathrm{~km}$ (Fig. 1), a seemingly large distance for one of the smallest amphibians in Europe. This probably indirectly reflects changes in the landscape that affect tree frogs at a smaller, local scale (roadkill, pollution, noise disturbances).

Replacing first-class road densities with traffic data corresponding to the same roads increased the observed deviance from $6 \%$ to $8 \%$ and widened the range of influence from $200 \mathrm{~m}$ to $400 \mathrm{~m}$. This result alone emphasizes the fact that not only do impermeable roads represent inhos- pitable habitat for tree frogs, but that vehicles are furthermore responsible for low densities of tree frogs. Whether direct mortality on roads (Fahrig et al. 1995; Hels \& Buchwald 2001) or indirect impacts such as pollution and/or disturbance are responsible for this pattern is unknown, although in some road segments of our study area massive tree frog casualties have been observed. Vehicular traffic can have a highly variable impact on amphibians, depending on the vagility of the species (Carr \& Fahrig 2001). Because the European tree frog is one of the most vagile species in Europe (Fog 1993), it might be more sensitive to traffic loads. Similarly, a negative effect of road proximity to breeding ponds on the probability of tree frog presence has been found (Pellet et al. 2004). Together, theses two studies show clear adverse effects of traffic abundance on tree frog populations.

The use of circular buffers assumes that the landscape has an isotropic effect on the tree frog, so that the species is affected by landscape elements equally in every direction from a given pond. It is probable that frictions in the landscape-such as barriers or inhospitable surfacesreduce movement patterns and reshape the ideal circular surface we used in this study into a noncircular form reflecting the actual use of the landscape matrix by tree frogs. These kinds of shapes could be modeled with friction algorithms based on the permeability of land uses to frog movements. Unfortunately, parameterization of such a home range is usually time- and cost-constraining because it requires intensive field work and expensive radiotracking materials (for the only published experiment with radiotracking of tree frogs, see Vos 1999).

Because our study was strictly correlational, the mechanisms of causality between predictors used and tree frog presence are mostly unknown and can only be hypothesized. The use of more proximal predictors more tightly related to the physiology of the species and/or including terrestrial habitats should give us stronger insights into the observed phenomena.

Because it is potentially applicable to any species functioning on a geographically defined patch basis, the concentric method proposed here should find many applications for identifying critical land-use units in highly heterogeneous landscapes, evaluating the range of influence of specific landscape elements, and, finally, mapping suitable areas for focal species. Although other studies have made use of buffers to study landscape patterns around amphibian breeding ponds (e.g., Vos \& Stumpel 1995; Findlay \& Houlahan 1997; Vos \& Chardon 1998; Edenhamn 1996; Johnson et al. 2002), the use of systematic buffers at regular radii permits the evaluation of landscape effects and their range of influence on pond-breeding amphibians. It also allowed the mapping of potential areas for amphibian breeding sites, which is of great importance in conservation management. This is especially true for the European tree frog in western Switzerland, where the lack of breeding ponds seems to be an important 


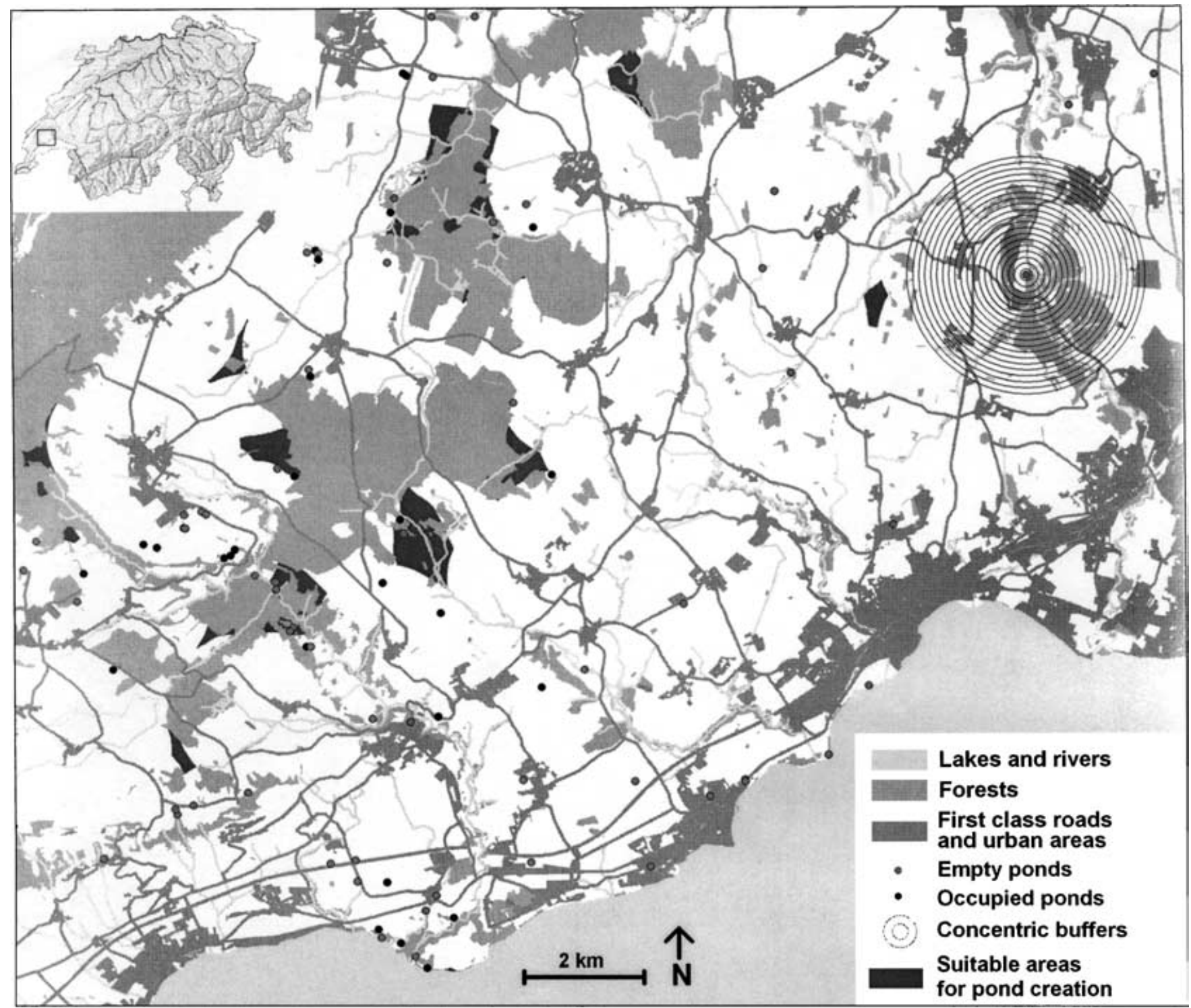

Figure 3. The study area in western Switzerland, distribution of studied ponds, illustration of the concentric design on one of the 76 ponds, and suitable locations for tree frog breeding ponds (distance of more than $1100 \mathrm{~m}$ from urban areas and $500 \mathrm{~m}$ from first-class roads).

cause of decline (Pellet \& Neet 2001; Pellet et al. 2002). This lack of breeding ponds is emphasized by the low occurrence of ponds in the potentially suitable surfaces we mapped. The mapping method could be improved by the introduction of geographically defined probabilities of occurrence instead of the binary suitable-or-unsuitablesurfaces approach. This would facilitate fine-scale identification of areas less affected by adverse landscape parameters. Restricting the wetland creation effort to these areas would enable conservation managers to focus on a limited surface, maximizing the probability of tree frog presence. Combined with pond-level characterization and identification of dispersal corridors, the concentric method shows great potential in conservation plans that create new ponds suitable for breeding of Hyla arborea and possibly other species.

\section{Acknowledgments}

This work was funded by the Centre de Conservation de la Faune et de la Nature du canton de Vaud and the MAVA Foundation. The Service des routes du canton de Vaud provided traffic data. We are grateful to P. Patthey for his help during MapBasic algorithm development and to K. Parker, L.J. Lawson Handley, J. Parker, and S. Sachot for their comments. We also thank two anonymous reviewers for their comments on the manuscript. 


\section{Literature Cited}

Alford, R. A., and S. J. Richards. 1999. Global amphibian declines: a problem in applied ecology. Annual Review of Ecology and Systematics 30:133-165.

Blaustein, A. R., D. B. Wake, and W. P. Sousa. 1994. Amphibian decline: judging stability, persistence, and susceptibility of populations to local and global extinctions. Conservation Biology 8: 60-71.

Blaustein, A. R., T. L. Root, J. M. Kiesecker, L. K. Belden, D. H. Olson, and D. M. Green. 2002. Amphibian phenology and climate change. Conservation Biology 16:1454-1455.

Borgula, A. 1993. Causes of the decline in Hyla arborea. Pages 71-80 in A. H. P. Stumpel and U. Tester, editors. Ecology and conservation of the European tree frog. Institute for Forestry and Nature Research, Wageningen, The Netherlands.

Brönmark, C., and P. Edenhamn. 1994. Does the presence of fish affect the distribution of tree frogs (Hyla arborea)? Conservation Biology 8:841-845.

Carlson, A., and P. Edenhamn. 2000. Extinction dynamics and the regional persistence of a tree frog metapopulation. Proceedings of the Royal Society of London Series B 267:1311-1313.

Carr, L. W., and L. Fahrig. 2001. Effect of road traffic on two amphibian species of differing vagility. Conservation Biology 15:1071-1078.

Delis, P. R., H. R. Mushinsky, and E. D. McCoy. 1996. Decline of some west-central Florida anuran populations in response to habitat degradation. Biodiversity and Conservation 5:1579-1595.

Duelli, P. 1994. Liste rouge des espèces animales menacées de Suisse. Office fédéral de l'environnement des forêts et du paysage, Bern.

Edenhamn, P. 1996. Spatial dynamics of the European tree frog (Hyla arborea L.) in a heterogeneous landscape. Ph.D. thesis. Swedish University of Agricultural Sciences, Uppsala.

Fahrig, L., J. H. Pedlar, S. E. Pope, P. D. Taylor, and J. F. Wegner. 1995. Effect of road traffic on amphibian density. Biological Conservation 73:177-182.

Findlay, C. S., and J. Houlahan. 1997. Anthropogenic correlates of species richness in southeastern Ontario wetlands. Conservation Biology 11:1000-1009.

Fog, K. 1988. The causes of decline of Hyla arborea on Bornholm. Memoranda Societa Fauna Flora Fennica 64:122-123.

Fog, K. 1993. Migration in the tree frog Hyla arborea. Pages 55-64 in A. H. P.Stumpel and U. Tester, editors. Ecology and conservation of the European tree frog. Institute for Forestry and Nature Research, Wageningen, The Netherlands.

Geiger, A. 1995. Der Laubfrosch (Hyla arborea L.): Ökologie und Artenschutz. Deutschen Gesellschaft für Herpetologie und Terrarienkunde, Bonn.

Green, D. M. 1997. Perspectives on amphibian population declines: defining the problem and searching for answers. Herpetological Conservation 1:291-308.

Green, D. M. 2003. The ecology of extinction: population fluctuation and decline in amphibians. Biological Conservation 111: 331-343.

Grosse, W. R. 1994. Der Laubfrosch. Westarp Wissenschaften, Magdeburg, Germany.

Grosse, W. R., and A. Nöllert. 1993. The aquatic habitat of the European tree frog, Hyla arborea. Pages 37-46 in A. H. P. Stumpel and U. Tester, editors. Ecology and conservation of the European tree frog. Institute for Forestry and Nature Research, Wageningen, The Netherlands.

Grossenbacher, K. 1988. Atlas de distribution des amphibiens de Suisse. Ligue Suisse pour la protection de la Nature, Basel, Switzerland.

Hels, T., and E. Buchwald. 2001. The effect of road kill on amphibian populations. Biological Conservation 99:331-340.

Hosmer, D. W., and S. Lemeshow. 1989. Applied logistic regression. Wiley Interscience, New York.

Houlahan, J. E., C. S. Findlay, B. R. Schmidt, A. H. Meyer, and S. L.
Kuzmin. 2000. Quantitative evidence for global amphibian population declines. Nature 404:752-755.

Jaberg, C., and A. Guisan. 2001. Modelling the distribution of bats in relation to landscape structure in a temperate mountain environment. Journal of Applied Ecology 38:1169-1181.

Johnson, C. M., L. B. Johnson, C. Richards, and V. Beasley. 2002. Predicting the occurrence of amphibians: an assessment of multiple-scale models. Pages 157-170 in J. M. Scott, P. J. Heglund, and M. L. Morrison, editors. Predicting species occurrence: issues of accuracy and scale. Island Press, Covelo, California.

Lehtinen, R. M., S. M. Galatowitsch, and J. R. Tester. 1999. Consequences of habitat loss and fragmentation for wetland amphibian assemblages. Wetlands 19:1-12.

Pavignano, I., C. Giacoma, and S. Castellano. 1990. A multivariate analysis of amphibian habitat determinants in north western Italy. Amphibia-Reptilia 11:311-324.

Pellet, J., and C. Neet. 2001. La rainette verte (Hyla arborea: Anura) dans le canton de Vaud: un état des lieux. Bulletin de la Société vaudoise des Sciences Naturelles 87:287-303.

Pellet, J., S. Dubey, and S. Hoehn. 2002. Les amphibiens du bassin de l'Aubonne: distribution et analyse d'habitat. Bulletin de la Société vaudoise des Sciences Naturelles 88:41-57.

Pellet, J., S. Hoehn, and N. Perrin. 2004. Multiscale determinants of tree frog (Hyla arborea L.) calling ponds in western Switzerland. Biodiversity and Conservation in press.

Pope, K. L., L. Fahrig, and H. G. Merriam. 2000. Landscape complementation and metapopulation effects on leopard frog populations. Ecology 81:2498-2508.

Schneider, H. 1993. Behavioural and bioacoustic studies in tree frogs. Pages 17-20 in A. H. P. Stumpel and U. Tester, editors. Ecology and conservation of the European tree frog. Institute for Forestry and Nature Research, Wageningen, The Netherlands.

Semlitsch, R. D. 1998. Biological delineation of terrestrial buffer zones for pond-breeding salamanders. Conservation Biology 12:11131119.

Semlitsch, R. D., and J. R. Bodie. 1998. Are small, isolated wetlands expendable? Conservation Biology 12:1129-1133.

Sjögren-Gulve, P., and C. Ray. 1996. Using logistic regression to model metapopulation dynamics: large scale forestry extirpates the pool frog. Pages 111-137 in D. R. McCullough, editor. Metapopulations and wildlife conservation. Island Press, Washington D.C.

Sokal, R. R., and F. J. Rohlf. 1995. Biometry. Freeman, New York.

Stumpel, A. H. P. 1993. The terrestrial habitat of Hyla arborea. Pages 47-54 in A. H. P. Stumpel and U. Tester, editors. Ecology and conservation of the European tree frog. Institute for Forestry and Nature Research, Wageningen, The Netherlands.

Stumpel, A. H. P., and G. Hanekamp. 1986. Habitat and ecology of Hyla arborea in the Netherlands. Pages 409-411 in Z. Rocek, editor. Studies in herpetology. Charles University, Prague, Czech Republic.

Swisstopo, Office Fédéral de la Topographie. 2003. Vector25. Swisstopo, Bern.

Tester, U. 1990. Artenschuetzerische relevante Aspekte zur Oekologie des Laubfroschs (Hyla arborea L.). Ph.D. thesis. Medezinische Biologie UNI Basel, Basel, Switzerland.

Vos, C. C. 1999. A frog's eye view on the landscape. Ph.D. thesis. In stitute for Forestry and Nature Research, University of Wageningen, Wageningen, The Netherlands.

Vos, C. C., and A. H. P. Stumpel. 1995. Comparison of habitatisolation parameters in relation to fragmented distribution patterns in the tree frog (Hyla arborea). Landscape Ecology 11: 203-214

Vos, C. C., and J. P. Chardon. 1998. Effects of habitat fragmentation and road density on the distribution pattern of the moor frog Rana arvalis. Journal of Applied Ecology 35:44-56.

Welsh, H. H., and A. J. Lind 2002. Multiscale habitat relationships of stream amphibians in the Klamath-Siskiyou region of California and Oregon. Journal of Wildlife Management 66:581-602. 